\title{
Halomonas kribbensis sp. nov., a novel moderately halophilic bacterium isolated from a solar saltern in Korea
}

\author{
Correspondence \\ Chang-Jin Kim \\ changjin@kribb.re.kr
}

\author{
Che Ok Jeon, ${ }^{1}$ Jee-Min Lim, ${ }^{2}$ Jung Ro Lee, ${ }^{1}$ Gye Suk Lee, ${ }^{2}$ \\ Dong-Jin Park, ${ }^{2}$ Jae-Chan Lee, ${ }^{2}$ Hyun-Woo Oh ${ }^{2}$ and Chang-Jin Kim ${ }^{2}$ \\ ${ }^{1}$ Division of Applied Life Science, EB-NCRC, PMBBRC, Gyeongsang National University, Jinju, \\ 660-701, Republic of Korea \\ ${ }^{2}$ Korea Research Institute of Bioscience and Biotechnology, 52 Oeundong, Yusong, \\ Daejeon 305-333, Republic of Korea
}

The family Halomonadaceae, which was originally erected by Franzmann et al. (1989) to accommodate the genera Halomonas (Vreeland et al., 1980) and Deleya (Baumann et al., 1983), currently includes four genera of halophilic/ halotolerant bacteria, i.e. Halomonas, Chromohalobacter, Alcanivorax and Cobetia, and two genera of non-halophilic/ halotolerant bacteria, i.e. Zymobacter and Carnimonas (Arahal et al., 2001, 2002a; Dobson \& Franzmann, 1996; Garriga et al., 1998; Yakimov et al., 1998). The members of the genus Halomonas comprise moderately halophilic, chemoorganotrophic, Gram-negative rods and are widely distributed in saline habitats. During the last decade, many species have been assigned to the genus Halomonas, but a number of them have since been reclassified and their nomenclature changed because they are phylogenetically heterogeneous (Arahal et al., 2001, 2002b; Mellado et al., 1995; Ventosa et al., 1998). During the course of studying saline environments, we have isolated halophilic,

The GenBank/EMBL/DDBJ accession number for the $16 \mathrm{~S}$ rRNA gene sequence of strain $\mathrm{BH}_{843^{\top}}$ is $\mathrm{DQ} 280368$.

A transmission electron micrograph of a negatively stained cell of strain $\mathrm{BH} 843^{\top}$ and a table detailing the cellular fatty acid compositions of strain $\mathrm{BH} 843^{\top}$ and related Halomonas species are available with the online version of this paper.
Gram-negative bacteria from a solar saltern (J. C. Lee et al., 2005; Lim et al., 2004). This paper describes a novel species belonging to the genus Halomonas.

Strain $\mathrm{BH} 843^{\mathrm{T}}$ was isolated from a solar saltern of the Yellow Sea in Korea. For the isolation, a soil sample was serially diluted in a $10 \%(\mathrm{w} / \mathrm{v})$ saline solution and spread on marine agar 2216 (MA; Difco) supplemented with $10 \%$ (w/v) $\mathrm{NaCl}$ (final $\mathrm{NaCl}$ concentration, $11.94 \%, w / v$ ) and incubated for 2 days at $32{ }^{\circ} \mathrm{C}$. Except where indicated, the isolate was routinely grown aerobically for 2 days at $32{ }^{\circ} \mathrm{C}$ on MA supplemented with $3 \%(\mathrm{w} / \mathrm{v}) \mathrm{NaCl}$. The $\mathrm{NaCl}$ requirement and tolerance were determined in nutrient broth (Difco) supplemented with modified artificial seawater containing the following $\left(1^{-1}\right): 0-20 \% \mathrm{NaCl}(\mathrm{w} / \mathrm{v})$, $5.94 \mathrm{~g} \mathrm{MgSO}_{4} \cdot 7 \mathrm{H}_{2} \mathrm{O}, 4.53 \mathrm{~g} \mathrm{MgCl}_{2} \cdot 6 \mathrm{H}_{2} \mathrm{O}, 0.64 \mathrm{~g} \mathrm{KCl}$ and $1.3 \mathrm{~g} \mathrm{CaCl}_{2}$. Growth was tested at different temperatures $\left(4-55^{\circ} \mathrm{C}\right)$ and at different $\mathrm{pH}$ values $(4.0-10.0)$ in marine broth (Difco) supplemented with $3 \%(\mathrm{w} / \mathrm{v}) \mathrm{NaCl}$. Media with different $\mathrm{pH}$ values were prepared using appropriate biological buffers: $\mathrm{Na}_{2} \mathrm{HPO}_{4} / \mathrm{NaH}_{2} \mathrm{PO}_{4}$ buffer, $\mathrm{Na}_{2} \mathrm{CO}_{3} /$ $\mathrm{NaHCO}_{3}$ buffer and $\mathrm{Na}_{2} \mathrm{HPO}_{4} / \mathrm{NaOH}$ buffer were used for $\mathrm{pH}$ values below 8.0, $\mathrm{pH} 8.0-10.0$ and $\mathrm{pH} 11.0$, respectively (Gomori, 1955). The cellular morphology of strain $\mathrm{BH} 843^{\mathrm{T}}$ was examined using light microscopy and transmission electron microscopy as described by E. M. Lee et al. (2005). 
Motility was assessed at 12 and $36 \mathrm{~h}$ in wet mounts under a light microscope (E600; Nikon). Gram staining was determined by using the bioMérieux Gram stain kit according to the manufacturer's instructions. Oxidase activity was tested using a Bactident oxidase strip (Merck) and catalase activity was determined by assessing bubble production in a $3 \%(\mathrm{v} / \mathrm{v})$ hydrogen peroxide solution. Nitrate reduction and the hydrolysis of aesculin, casein, gelatin, L-tyrosine and urea were determined on MA supplemented with $3 \%(\mathrm{w} / \mathrm{v}) \mathrm{NaCl}$ according to the methods described by Cowan \& Steel (1965), Lanyi (1987) and Smibert \& Krieg (1994). Growth under anaerobic conditions was determined after 7 days incubation at $32{ }^{\circ} \mathrm{C}$ on MA supplemented with $3 \%(\mathrm{w} / \mathrm{v}) \mathrm{NaCl}$, using an anaerobic chamber.

Strain $\mathrm{BH} 843^{\mathrm{T}}$ formed yellow-cream and circular/slightly irregular colonies when grown at $32{ }^{\circ} \mathrm{C}$ for 2 days. The strain grew in nutrient broth supplemented with 1-14\% (w/v) $\mathrm{NaCl}$, the optimum concentration being $5 \%(\mathrm{w} / \mathrm{v})$. The strain did not grow without added $\mathrm{NaCl}$ or in the presence of more than $15 \%(\mathrm{w} / \mathrm{v}) \mathrm{NaCl}$. Growth occurred at $\mathrm{pH}$ 5.5-9.5 (optimum, $\mathrm{pH}$ 8.0-8.5) in marine broth supplemented with $3 \%(\mathrm{w} / \mathrm{v}) \mathrm{NaCl}$. Growth was observed at temperatures between 10 and $40{ }^{\circ} \mathrm{C}$, the optimum growth temperature being $32-35{ }^{\circ} \mathrm{C}$. The cells were cocci measuring $1.8-2.2 \mu \mathrm{m}$ in diameter or short rods 1.4 $1.8 \mu \mathrm{m}$ wide and $1.8-2.6 \mu \mathrm{m}$ long after 2 days incubation at $32{ }^{\circ} \mathrm{C}$ on MA supplemented with $3 \%(\mathrm{w} / \mathrm{v}) \mathrm{NaCl}$, and were motile by means of a single flagellum (see Supplementary Fig. S1 available in IJSEM Online). The strain showed oxidase-negative and catalase-positive reactions and was able to reduce nitrate to nitrite. Anaerobic growth was not observed during 7 days incubation under anaerobic conditions at $32{ }^{\circ} \mathrm{C}$ on MA supplemented with $3 \%(w / v) ~ \mathrm{NaCl}$. Other phenotypic features of strain $\mathrm{BH} 843^{\mathrm{T}}$ are presented in Table 1 and in the description of the novel species. Some of these features are in accordance with those of known members of the genus Halomonas, whereas others serve to differentiate strain $\mathrm{BH} 843^{\mathrm{T}}$ from closely related Halomonas species (Table 1).

The whole-cell fatty acids of strain $\mathrm{BH} 843^{\mathrm{T}}$ were analysed using GC/MS according to the instructions of the Microbial Identification System (MIDI; Microbial ID) after cultivation on MA for 2 days at $32{ }^{\circ} \mathrm{C}$. Isoprenoid quinones were analysed as described by Komagata \& Suzuki (1987). The DNA G+C content (mol\%) was determined by using reversed-phase HPLC according to the method of Tamaoka \& Komagata (1984). The predominant isoprenoid quinone of strain $\mathrm{BH} 843^{\mathrm{T}}$ was Q-9. The major cellular fatty acids of strain $\mathrm{BH} 843^{\mathrm{T}}$ grown on MA were $\mathrm{C}_{16: 0}(26.30 \%), \mathrm{C}_{19: 0}$ cyclo $\omega 8 c(25.77 \%)$ and $\mathrm{C}_{17: 0}$ cyclo $(15.20 \%$ ) (see Supplementary Table S1 available in IJSEM Online). The major fatty acid profile of strain $\mathrm{BH} 843^{\mathrm{T}}$ was similar to those of members of the genus Halomonas (Bouchotroch et al., 2001; Lim et al., 2004; Yoon et al., 2002). The DNA G + C content of strain $\mathrm{BH} 843^{\mathrm{T}}$ was $66 \mathrm{~mol} \%$, which is within the range for recognized Halomonas species (Garcia et al., 2004; Mata et al., 2002; Poli et al., 2007; Ventosa et al., 1998).

PCR amplification of the 16S rRNA gene of strain $\mathrm{BH} 843^{\mathrm{T}}$ was performed using primers $27 \mathrm{f}$ and 1492r (Lane, 1991)

Table 1. Differential phenotypic characteristics of strain $B H 843^{\top}$ and selected related type species

Species/strain: 1, BH843 ${ }^{\mathrm{T}}$; 2, H. muralis; 3, H. pantelleriensis; 4, H. desiderata; 5, H. anticariensis. Data are from Heyrman et al. (2002), Romano et al. (1996), Berendes et al. (1996) and Martínez-Cánovas et al. (2004), respectively. +, Positive; -, negative; NA, data not available.

\begin{tabular}{|c|c|c|c|c|c|}
\hline Characteristic & 1 & 2 & 3 & 4 & 5 \\
\hline Cell morphology & Cocci or short rods & Rods & Rods or pleomorphic & Rods & Rods \\
\hline Size $(\mu \mathrm{m})$ & $1.4-1.8 \times 1.8-2.6$ & $0.4-0.6 \times 1.5-3.0$ & $0.4-0.7 \times 1.4-2.6$ & $0.4-0.6 \times 1.0-2.6$ & $0.75-1.0 \times 3.0-3.5$ \\
\hline Flagellation & Single flagellum & Peritrichous & Peritrichous & Peritrichous & Peritrichous \\
\hline $\mathrm{NaCl}$ range $(\%, \mathrm{w} / \mathrm{v})$ & $1-14$ & $0-15$ & $1.25-15$ & $0-18$ & $0.5-15.0$ \\
\hline $\mathrm{NaCl}$ optimum $(\%, w / v)$ & $5-6$ & $2.5-10$ & 10 & NA & 7.5 \\
\hline Temperature range $\left({ }^{\circ} \mathrm{C}\right)$ & $10-40$ & $10-35$ & $10-44$ & $10-48$ & $20-45$ \\
\hline Oxidase & - & + & + & + & + \\
\hline \multicolumn{6}{|l|}{ Hydrolysis of: } \\
\hline Aesculin & + & + & NA & NA & - \\
\hline Casein & - & NA & - & - & - \\
\hline Gelatin & + & - & - & - & - \\
\hline $\begin{array}{l}\text { DNA G }+ \text { C content } \\
(\mathrm{mol} \%)\end{array}$ & 66.0 & 62.4 & 65.0 & 66.0 & 61.4 \\
\hline
\end{tabular}


and the PCR product was then cloned (using a TOPO cloning kit; Invitrogen) and sequenced. The resultant $16 \mathrm{~S}$ rRNA gene sequence $(1417 \mathrm{nt})$ of strain $\mathrm{BH} 843^{\mathrm{T}}$ was compared with 16S rRNA gene sequences available from GenBank, using the BLAST program (http://www.ncbi.nlm. nih.gov/blast/), to determine its approximate phylogenetic affiliation; alignment with sequences from closely related members was performed using CLUSTAL W software (Thompson et al., 1994). Phylogenetic trees were constructed using three different methods available with PHYLIP, version 3.6 (Felsenstein, 2002): the neighbourjoining, maximum-likelihood and maximum-parsimony algorithms. Values for similarities between the sequence of the isolate and those of related members of the genus Halomonas were computed using Similarity Matrix, version 1.1 (Ribosomal Database Project II; http:// 35.8.164.52/html/; Cole et al., 2003). A bootstrap analysis was performed according to the algorithm of the Kimura two-parameter model (Kimura, 1980) of the neighbourjoining method in the PHYLIP package. DNA-DNA hybridization was carried out to evaluate the genomic DNA relatedness between strain $\mathrm{BH} 843^{\mathrm{T}}$ and related Halomonas type strains by using the fluorometric microplate method (Ezaki et al., 1989). Halomonas anticariensis LMG $22089^{\mathrm{T}}$, Halomonas pantelleriensis DSM $9661^{\mathrm{T}}$, Halomonas muralis LMG $20969^{\mathrm{T}}$, Halomonas alimentaria KCCM $41042^{\mathrm{T}}$ and Halomonas pacifica DSM $4742^{\mathrm{T}}$ were used as reference strains for DNA-DNA hybridization. Reference strains were grown in marine broth at appropriate temperatures. Chromosomal DNA from $H$. pantelleriensis DSM $9661^{\mathrm{T}}$, H. alimentaria KCCM $41042^{\mathrm{T}}$ and $H$. pacifica DSM $4742^{\mathrm{T}}$ was isolated and purified according to the standard method described by Yoon et al. (1996). However, genomic DNA from strain $\mathrm{BH} 843^{\mathrm{T}}, H$. muralis LMG $20969^{\mathrm{T}}$ and $H$. anticariensis LMG $22089^{\mathrm{T}}$ was extracted using a genomic DNA purification kit (Promega), according to the manufacturer's instructions, and amplified by means of a multiple displacement amplification method (Teles et al., 2007) because genomic DNA extractions from these organisms always failed if the standard method was used. Fluorometric data recorded after 30 min incubation were used to calculate the DNADNA hybridization values. The highest and lowest values in each sample were excluded and the remaining three values were used to calculate the similarity value. The DNA relatedness values are means of three values.

The tree constructed using neighbour-joining analysis clearly showed that the isolate forms a distinct phyletic line (with $57 \%$ bootstrap support) within the genus Halomonas (Fig. 1). The topologies of phylogenetic trees constructed using the maximum-likelihood and maximum-parsimony algorithms also supported the notion that the isolate belongs to the genus Halomonas and can be differentiated from recognized species of the genus Halomonas (data not shown). Strain $\mathrm{BH} 843^{\mathrm{T}}$ showed $16 \mathrm{~S}$ rRNA gene sequence similarities of 95.1, 95.0, 94.9 and $94.8 \%$ with respect to its closest relatives, $H$. muralis LMG
$20969^{\mathrm{T}}, H$. anticariensis LMG $22089^{\mathrm{T}}, H$. pantelleriensis DSM $9661^{\mathrm{T}}$ and Halomonas desiderata DSM $9502^{\mathrm{T}}$, respectively. The values for DNA-DNA relatedness between strain $\mathrm{BH} 843^{\mathrm{T}}$ and the type strains of closely related Halomonas species were $19,25,18,14$ and $16 \%$ for $H$. anticariensis LMG $22089^{\mathrm{T}}, H$. pantelleriensis DSM $9661^{\mathrm{T}}$, H. muralis LMG $20969^{\mathrm{T}}$, H. alimentaria KCCM $41042^{\mathrm{T}}$ and H. pacifica DSM $4742^{\mathrm{T}}$, respectively, which are clearly below the $70 \%$ threshold generally accepted for species delineation (Christensen et al., 2001; Rosselló-Mora \& Amann, 2001). On the basis of the phenotypic and phylogenetic data, it is proposed that strain $\mathrm{BH} 843^{\mathrm{T}}$ represents a novel species within the genus Halomonas, for which the name Halomonas kribbensis sp. nov. is proposed.

\section{Description of Halomonas kribbensis sp. nov.}

Halomonas kribbensis (krib.ben'sis. N.L. fem. adj. Kribbensis pertaining to KRIBB, arbitrary adjective formed from the acronym of the Korea Research Institute of Bioscience and Biotechnology, where taxonomic studies of this species were performed).

Cells are Gram-negative, non-spore-forming cocci or rods. Colonies are yellow-cream and circular/slightly irregular. Cells are motile, each cell having a flagellum. Grows at

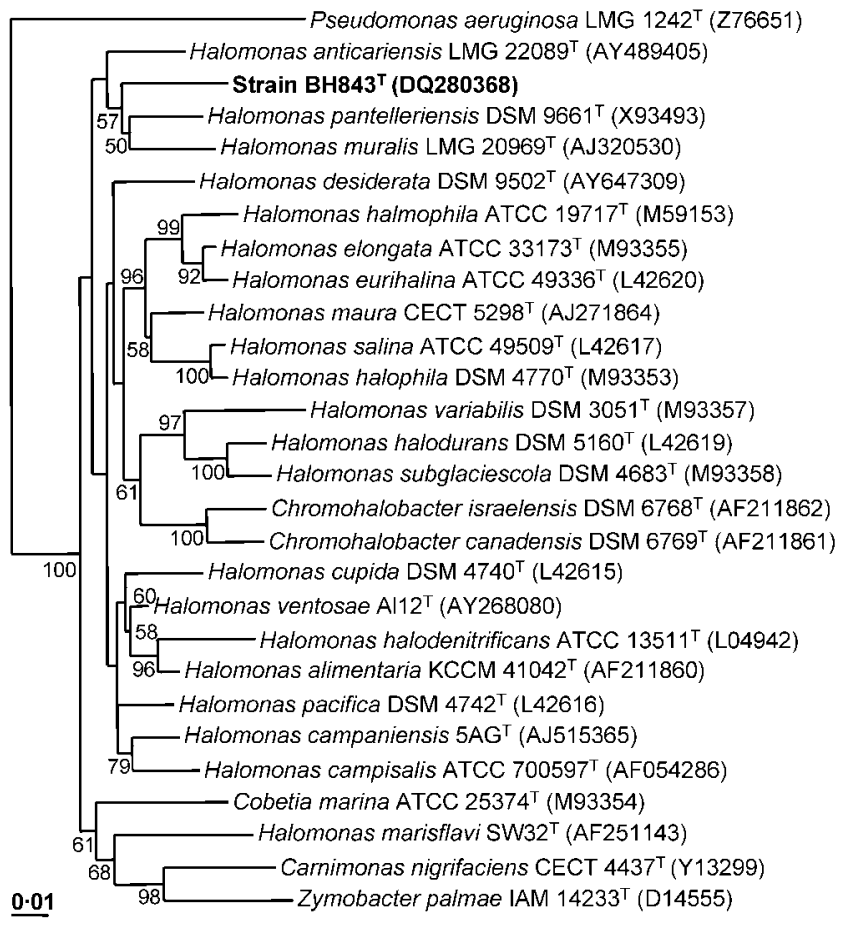

Fig. 1. Neighbour-joining phylogenetic tree, based on $16 \mathrm{~S}$ rRNA gene sequences, showing the relationships between strain $\mathrm{BH}_{843}{ }^{\top}$ and related taxa. Bootstrap percentages (based on 1000 replicates) greater than $50 \%$ are shown. Pseudomonas aeruginosa LMG $1242^{\top}$ was used as an outgroup. Bar, 0.01 changes per nucleotide position. 
salinities in the range 1-14\% (w/v) NaCl. Good growth occurs at $5 \%(\mathrm{w} / \mathrm{v}) \mathrm{NaCl}$. Growth occurs between 10 and $40{ }^{\circ} \mathrm{C}$ (optimum, $32-35{ }^{\circ} \mathrm{C}$ ) and at $\mathrm{pH} 5.5-9.5$ (optimum, $\mathrm{pH}$ 8.0-8.5). Oxidase-negative and catalase-positive. Nitrate is reduced to nitrite. Aesculin and gelatin are hydrolysed, but casein, L-tyrosine and urea are not hydrolysed. The predominant isoprenoid quinone is Q-9. The major fatty acids are $\mathrm{C}_{16: 0}, \mathrm{C}_{19: 0}$ cyclo $\omega 8 c$ and $\mathrm{C}_{17: 0}$ cyclo. The DNA G+C content is $66 \mathrm{~mol} \%$.

The type strain, $\mathrm{BH} 843^{\mathrm{T}}\left(=\right.$ KCTC $\left.12584^{\mathrm{T}}=\mathrm{DSM} 17892^{\mathrm{T}}\right)$, was isolated from a solar saltern in Korea.

\section{Acknowledgements}

This work was supported by the 21C Frontier Microbial Genomics and Application Center Program, Ministry of Science and Technology, and by a grant from KRIBB Research Initiative Program, Republic of Korea.

\section{References}

Arahal, D. R., García, M. T., Ludwig, W., Schleifer, K. H. \& Ventosa, A. (2001). Transfer of Halomonas canadensis and Halomonas israelensis to the genus Chromohalobacter as Chromohalobacter canadensis comb. nov. and Chromohalobacter israelensis comb. nov. Int J Syst Evol Microbiol 51, 1443-1448.

Arahal, D. R., Castillo, A. M., Ludwig, W., Schleifer, K. H. \& Ventosa, A. (2002a). Proposal of Cobetia marina gen. nov., comb. nov., within the family Halomonadaceae, to include the species Halomonas marina. Syst Appl Microbiol 25, 207-211.

Arahal, D. R., Ludwig, W., Schleifer, K. H. \& Ventosa, A. (2002b). Phylogeny of the family Halomonadaceae based on 23S and 16S rDNA sequence analyses. Int J Syst Evol Microbiol 52, 241-249.

Baumann, L., Bowditch, R. D. \& Baumann, P. (1983). Description of Deleya gen. nov. created to accommodate the marine species Alcaligenes aestus, A. pacificus, A. cupidus, A. venustus, and Pseudomonas marina. Int J Syst Bacteriol 33, 793-802.

Berendes, F., Gottschalk, G., Heine-Dobbernack, E., Moore, E. R. B. \& Tindall, B. J. (1996). Halomonas desiderata sp. nov., a new alkaliphilic, halotolerant and denitrifying bacterium isolated from a municipal sewage works. Syst Appl Microbiol 19, 158-167.

Bouchotroch, S., Quesada, E., Moral, A. D., Llamas, I. \& Béjar, V. (2001). Halomonas maura sp. nov., a novel moderately halophilic, exopolysaccharide-producing bacterium. Int J Syst Evol Microbiol 51, 1625-1632.

Christensen, H., Bisgaard, M., Frederiksen, W., Mutters, R., Kuhnert, P. \& Olsen, J. E. (2001). Is characterization of a single isolate sufficient for valid publication of a new genus or species? Proposal to modify recommendation 30b of the Bacteriological Code (1990 Revision). Int J Syst Evol Microbiol 51, 2221-2225.

Cole, J. R., Chai, B., Marsh, T. L., Farris, R. J., Wang, Q., Kulam, S. A., Chandra, S., McGarrell, D. M., Schmidt, T. M. \& other authors (2003). The ribosomal database project (RDP-II): previewing a new autoaligner that allows regular updates and the new prokaryotic taxonomy. Nucleic Acids Res 31, 442-443.

Cowan, S. T. \& Steel, K. J. (1965). Manual for the Identification of Medical Bacteria. London: Cambridge University Press.

Dobson, S. J. \& Franzmann, P. D. (1996). Unification of the genera Deleya (Baumann et al. 1983), Halomonas (Vreeland et al. 1980), and Halovibrio (Fendrich 1988) and the species Paracoccus halodenitrificans
(Robinson and Gibbons 1952) into a single genus, Halomonas, and placement of the genus Zymobacter in the family Halomonadaceae. Int $J$ Syst Bacteriol 46, 550-558.

Ezaki, T., Hashimoto, Y. \& Yabuuchi, E. (1989). Fluorometric deoxyribonucleic acid-deoxyribonucleic acid hybridization in microdilution wells as an alternative to membrane filter hybridization in which radioisotopes are used to determine genetic relatedness among bacterial strains. Int J Syst Bacteriol 39, 224-229.

Felsenstein, J. (2002). PHYLIP (phylogeny inference package), version 3.6a. Distributed by the author. Department of Genome Sciences, University of Washington, Seattle, USA.

Franzmann, P. D., Wehmeyer, U. \& Stackebrandt, E. (1989). Halomonadaceae fam. nov., a new family of the class Proteobacteria to accommodate the genera Halomonas and Deleya. Syst Appl Microbiol 11, 16-19.

Garcia, M. T., Mellado, E., Ostos, J. C. \& Ventosa, A. (2004). Halomonas organivorans sp. nov., a moderate halophile able to degrade aromatic compounds. Int J Syst Evol Microbiol 54, 1723-1728.

Garriga, M., Ehrmann, M. A., Arnau, J., Hugas, M. \& Vogel, R. F. (1998). Carnimonas nigrificans gen. nov., sp. nov., a bacterial causative agent for black spot formation on cured meat products. Int J Syst Bacteriol 48, 677-686.

Gomori, G. (1955). Preparation of buffers for use in enzyme studies. In Methods in Enzymology, vol. 1, pp. 138-146. Edited by S. P. Colowick \& N. O. Kaplan. New York: Academic Press.

Heyrman, J., Balcaen, A., Vos, P. D. \& Swings, J. (2002). Halomonas muralis sp. nov., isolated from microbial biofilms colonizing the walls and murals of the Saint-Catherine chapel (Castle Herberstein, Austria). Int J Syst Evol Microbiol 52, 2049-2054.

Kimura, M. (1980). A simple method for estimating evolutionary rates of base substitutions through comparative studies of nucleotide sequences. J Mol Evol 16, 111-120.

Komagata, K. \& Suzuki, K. (1987). Lipid and cell wall analysis in bacterial systematics. Methods Microbiol 19, 161-207.

Lane, D. J. (1991). 16S/23S rRNA sequencing, In Nucleic Acid Techniques in Bacterial Systematics, pp. 115-175. Edited by E. Stackebrandt \& M. Goodfellow. Chichester: Wiley.

Lanyi, B. (1987). Classical and rapid identification methods for medically important bacteria. Methods Microbiol 19, 1-67.

Lee, E. M., Jeon, C. O., Choi, I., Chang, K. S. \& Kim, C.-J. (2005). Silanimonas lenta gen. nov., sp. nov., a slightly thermophilic and alkaliphilic gammaproteobacterium isolated from a hot spring. Int $J$ Syst Evol Microbiol 55, 385-389.

Lee, J. C., Jeon, C. O., Lim, J. M., Lee, S. M., Lee, J. M., Song, S. M., Park, D. J., Li, W. J. \& Kim, C.-J. (2005). Halomonas taeanensis sp. nov., a novel moderately halophilic bacterium isolated from a solar saltern in Korea. Int J Syst Evol Microbiol 55, 2027-2032.

Lim, J.-M., Yoon, J. H., Lee, J. C., Jeon, C. O., Park, D. J., Sung, C. K. \& Kim, C.-J. (2004). Halomonas koreensis sp. nov., a moderately halophilic bacterium isolated from a solar saltern in Korea. Int $J$ Syst Evol Microbiol 54, 2037-2042.

Martínez-Cánovas, M. J., Béjar, V., Martínez-Checa, F. \& Quesada, E. (2004). Halomonas anticariensis sp. nov., from Fuente de Piedra, a saline-wetland wildfowl reserve in Málaga, southern Spain. Int J Syst Evol Microbiol 54, 1329-1332.

Mata, J. A., Martínez-Cánovas, M. J., Quesada, E. \& Béjar, V. (2002). A detailed phenotypic characterization of the type strains of Halomonas species. Syst Appl Microbiol 25, 360-375.

Mellado, E., Moore, E. R., Nieto, J. J. \& Ventosa, A. (1995). Phylogenetic inferences and taxonomic consequences of $16 \mathrm{~S}$ ribosomal DNA 
sequence comparison of Chromohalobacter marismortui, Volcaniella eurihalina, and Deleya salina and reclassification of $V$. eurihalina as Halomonas eurihalina comb. nov. Int J Syst Bacteriol 45, 712-716.

Poli, A., Esposito, E., Orlando, P., Lama, L., Giordano, A., de Appolonia, F., Nicolaus, B. \& Gambacorta, A. (2007). Halomonas alkaliantarctica sp. nov., isolated from saline lake Cape Russell in Antarctica, an alkalophilic moderately halophilic, exopolysaccharideproducing bacterium. Syst Appl Microbiol 30, 31-38.

Romano, I., Nicolaus, B., Lama, L., Manca, M. C. \& Gambacorta, A. (1996). Characterization of a haloalkalophilic strictly aerobic bacterium, isolated from Pantelleria island. Syst Appl Microbiol 19, 326-333.

Rosselló-Mora, R. \& Amann, R. (2001). The species concept for prokaryotes. FEMS Microbiol Rev 25, 39-67.

Smibert, R. M. \& Krieg, N. R. (1994). Phenotypic characterization. In Methods for General and Molecular Bacteriology, pp. 607-654. Edited by P. Gerhardt. Washington, DC: American Society for Microbiology.

Tamaoka, J. \& Komagata, K. (1984). Determination of DNA base composition by reversed-phase high-performance liquid chromatography. FEMS Microbiol Lett 25, 125-128.

Teles, F., Haffajee, A. D. \& Socransky, S. S. (2007). Multiple displacement amplification as an aid in checkerboard DNA-DNA hybridization. Oral Microbiol Immunol 22, 118-125.
Thompson, J. D., Higgins, D. G. \& Gibson, T. J. (1994). Clustal W: improving the sensitivity of progressive multiple sequence alignment through sequence weighting, position-specific gap penalties and weight matrix choice. Nucleic Acids Res 22, 4673-4680.

Ventosa, A., Nieto, J. J. \& Oren, A. (1998). Biology of moderately halophilic aerobic bacteria. Microbiol Mol Biol Rev 62, 504-544.

Vreeland, R. H., Litchfield, C. D., Martin, E. L. \& Elliot, E. (1980). Halomonas elongata, a new genus and species of extremely salt tolerant bacteria. Int J Syst Bacteriol 30, 485-495.

Yakimov, M. M., Golyshin, P. N., Lang, S., Moore, E. R., Abraham, W. R., Lunsdorf, H. \& Timmis, K. N. (1998). Alcanivorax borkumensis gen. nov., sp. nov., a new, hydrocarbon-degrading and surfactant-producing marine bacterium. Int J Syst Bacteriol 48, 339-348.

Yoon, J.-H., Kim, H., Kim, S.-B., Kim, H.-J., Kim, W. Y., Lee, S. T., Goodfellow, M. \& Park, Y.-H. (1996). Identification of Saccharomonospora strains by the use of genomic DNA fragments and rRNA gene probes. Int J Syst Bacteriol 46, 502-505.

Yoon, J.-H., Lee, K.-C., Kho, Y.-H., Kang, K.-H., Kim, C.-J. \& Park, Y.-H. (2002). Halomonas alimentaria sp. nov., isolated from jeotgal, a traditional Korean fermented seafood. Int J Syst Evol Microbiol 52, 123-130. 